Revue d'histoire de l'Amérique française

DE REVUE D.HISTOIRE DE L'AMÉRIQUE FRANÇAISE

\title{
Prix d'Histoire du Canada offerts par la Fondation Lionel Groulx à tous les collèges classiques de la province de Québec
}

\section{J. Rémillard}

Volume 18, numéro 1, juin 1964

URI : https://id.erudit.org/iderudit/018111ar

DOI : https://doi.org/10.7202/018111ar

Aller au sommaire du numéro

Éditeur(s)

Institut d'histoire de l'Amérique française

ISSN

0035-2357 (imprimé)

1492-1383 (numérique)

Découvrir la revue

Citer ce document

Rémillard, J. (1964). Prix d'Histoire du Canada offerts par la Fondation Lionel Groulx à tous les collèges classiques de la province de Québec. Revue d'histoire de l'Amérique française, 18(1), 160-160. https://doi.org/10.7202/018111ar d'utilisation que vous pouvez consulter en ligne. 
Prix d'Histoire du Canada offerts par la Fondation Lionel Groulx à tous les collèges classiques de la province de Québec.

Pour la quatrième année, la Fondation Lionel Groulx vient d'offrir, à tous les collèges classiques du Québec, un grand prix d'Histoire du Canada. Elle a fait le choix, cette année, de Notre Grande Aventure - l'Empire français en Amérique $d u$ Nord (1535-1760), du chanoine Lionel Groulx. A une heure où tant de tâches exaltantes font appel à la jeunesse canadiennefrançaise, les directeurs de la Fondation ont pensé que cette œuvre de l'historien, qui relate l'un des grands faits de l'histoire de la Nouvelle-France, pouvait offrir une inspiration à la génération prochaine.

J. RÉmillaRd, sec. 